\title{
Screening of Genotypes to Identify the Resistance Source against Major Diseases of Soybean under High Disease Pressure Conditions
}

\author{
Pawan K. Amrate*, M. K. Shrivastava and Gyanendra Singh \\ Department of Plant Breeding and Genetics, Jawaharlal Nehru Krishi Vishwa Vidyalaya, \\ Jabalpur-482 004, India \\ *Corresponding author
}

\section{A B S T R A C T}

Charcoal rot and Aerial alight caused by Macrophomina phaseolina (Tassi) Goid and Rhizoctonia solani Kuhn, respectively are major biotic challenges across the country in soybean cultivation. The problem of disease can be overcome nicely by

\section{Keywords}

Resistance, Soybean, Charcoal rot, Aerial blight

Article Info

Accepted:

15 April 2020

Available Online:

10 May 2020 growing resistant variety and using integrated disease management practices. In this concern, for the identification of resistant source, total sixty genotypes including five check varieties namely Shivalik, JS 335, JS 95-60, JS 93-05 and NRC 7 were evaluated under high disease pressure during kharif 2019. The disease index of Rhizoctonia Aerial Blight (RAB) was varied from 0.75 to 37.50 per cent. Out of sixty, five and sixteen genotypes were exhibited highly and moderately resistant reaction against $\mathrm{RAB}$, respectively. In case of Charcoal rot (CR), severity in nine genotypes were reported more than 50 per cent and sixteen genotypes shown absolute resistance. For both diseases, five namely JS 21-71, JS 20-31, TG x - 849 D-13-4, JS 20-42 and JS 20-75 shown absolute resistance to CR plus highly resistance to RAB. Whereas nine i.e. DS 3109, EC 251358, JS 2079, JS 21-17, VP 1164, JS 20-69, JS 20-34, JS 20-53, MACS 1620 found to be absolute resistant (CR) plus moderately resistant (RAB).

\section{Introduction}

Soybean (Glycine max (L.) Merrill) is known for its high protein and oil content and grows across the world as most important oilseed crops in world. Soybean is cultivated as a kharif season crop in India and during 201617, it has occupied 10.97 million ha area with total production of 10.99 million tons whereas the productivity stand of $1002 \mathrm{~kg} / \mathrm{ha}$ in the country. Among states, Madhya Pradesh is still ranked first in area as well as in production and covers of 54.01 lakh ha area with the average productivity of $1020 \mathrm{~kg} / \mathrm{ha}$ and total production of 55.06 lakh ton during the same year of 2016-17 (Anonymous, 2018). In recent year, soybean production and the area coverage under cultivation in different district of M.P. has declined due regular occurring of abiotic and biotic 
stresses. In this concern, fungal causing disease like charcoal rot (CR) and Rhizoctonia aerial blight (RAB) have became major challenges in the production of soybean in the state. Both the diseases usually appear during reproductive stages of crop. Charcoal rot can caused complete plant mortality during reproductive stages of crop and formed black microsclerotia in the vascular tissues and on lower part of plant (Bradley and Rio, 2003). Rhizoctonia Aerial Blight caused light to dark brown spots, web like mycelium on foliage and formed sclerotia on above ground parts (Verma and Thapliyal, 1976). Identification and incorporation of resistance in high yielding genotypes is the best way to minimize the losses caused by disease. In looking to increasing view of incidences of diseases, in this field trial an attempt was made to know the resistance level of different genotypes under high disease pressure or hot spot condition.

\section{Materials and Methods}

A field evaluation trial for sixty genotypes including five old varieties (Shivalik, JS 335, JS 95-60, JS 93-05 and NRC 7) of soybean were conducted under AICRP on Soybean at JNKVV, Jabalpur during kharif 2019. This AICPR, Jabalpur centre is recognized as hot spot for both the diseases (RAB and CR) due to regular appearance of disease in moderate to severe form. All the genotypes were sown in augmented plot design each in two rows during last week of June, 2019.

No fungicides as seed treatment and foliar application were applied during the entire period of crop growth. Whereas other cultivation practices were followed as per the recommendation for the cultivation of soybean. Disease rating and grouping of genotypes were done as per the rating scale used in AICRP on soybean (Anonymous, 2012).

\section{Observation and Grouping of resistance Rhizoctonia Aerial Blight (RAB)}

Each genotype was observed regularly during the period of disease progress critically. Observation for RAB was taken on randomly selected ten plants from each genotype. Each selected plants were approximately divided into three positions as bottom, middle and top. In each position two to four leaves are graded and infected leaves were assigned 0-9 ratings/ grades which are given Table 1 based on the percent leaf area infected.

Per cent Disease index (PDI) Calculation:

These grades are then utilized for the calculation of PDI by using the following formula of Wheeler's (1969)

Per cent Disease Index $(\mathrm{PDI})=$

Sum of individual rating X $\frac{100}{\text { Max. Disease }}$

No. of leaves examined Max. Disease

On the basis of PDI, the genotypes/varieties were classified as follows:

\begin{tabular}{|l|l|}
\hline PDI & Categories \\
\hline $\mathbf{0 . 0}$ & Absolutely resistant \\
\hline $\mathbf{0 . 1}-\mathbf{1 . 0}$ & Highly resistant \\
\hline $\mathbf{1 . 1 - 1 0 . 0}$ & Moderately resistant \\
\hline $\mathbf{1 0 . 1 - 2 5 . 0}$ & Moderately susceptible \\
\hline $\mathbf{2 5 . 1 - 5 0 . 0}$ & Susceptible \\
\hline $\mathbf{> 5 0 . 0}$ & Highly susceptible \\
\hline
\end{tabular}

\section{Charcoal rot (CR)}

Charcoal rot mortality was observed before the maturity of crop in month of September. On the basis of dead and total plant in the particular line, the per cent mortality was calculated and accordingly the genotypes were classified as given below: 


\begin{tabular}{|l|l|l|}
\hline Score & Descriptions & Categories \\
\hline $\mathbf{0}$ & No mortality & $\begin{array}{l}\text { Absolutely resistant } \\
\text { (AR) }\end{array}$ \\
\hline $\mathbf{1}$ & $1 \%$ mortality & $\begin{array}{l}\text { Highly resistant } \\
\text { (HR) }\end{array}$ \\
\hline $\mathbf{3}$ & $\begin{array}{l}1.1 \text { to } 10 \% \\
\text { mortality } \%\end{array}$ & $\begin{array}{l}\text { Moderately } \\
\text { resistant (MR) }\end{array}$ \\
\hline $\mathbf{5}$ & $\begin{array}{l}10.1 \text { to } 25 \% \\
\text { mortality }\end{array}$ & $\begin{array}{l}\text { Moderately } \\
\text { susceptible (MS) }\end{array}$ \\
\hline $\mathbf{7}$ & $\begin{array}{l}\text { 25.1 to 50 \% } \\
\text { mortality }\end{array}$ & Susceptible (S) \\
\hline $\mathbf{9}$ & $\begin{array}{l}\text { More than 50 } \\
\text { \% mortality }\end{array}$ & $\begin{array}{l}\text { Highly susceptible } \\
\text { (HS) }\end{array}$ \\
\hline
\end{tabular}

\section{Results and Discussion}

\section{Resistance to aerial blight}

All the tested genotypes were observed critically during entire crop period. The symptoms of RAB have started appearing after $15^{\text {th }}$ of august and highest severity was noticed in the month of September.

The disease index was varied from 0.75 to 37.50 per cent. Out of sixty, five i.e. JS 21-71, JS 20-31, TG x - 849D-13-4, JS 20-42, JS 20-
75 and sixteen i.e. CAT 1241A, EC 39177 , DS 3109, EC 251358, JS 20-79, JS 21-17, VP 1164, JS 20-69, JS 20-34, JS 20-53, MACS 1620, BHATT, VP 1162, EC 241807, EC 114573, JS 95-60(c) were exhibited highly and moderately resistant reaction against $\mathrm{RAB}$, respectively. Whereas remaining thirty two and seven were found to be moderately susceptible to susceptible, respectively.

\section{Resistance to charcoal rot}

Plant death in different genotypes due to charcoal rot was observed during reproductive stages especially just before the maturity of crop. Out of sixty, nine genotypes were reported more than 50 per cent mortality and grouped under highly susceptible against CR disease. In resistant entries, sixteen namely JS 21-71, JS 20-31, TG x - 849D-13-4, JS 2042, JS 20-75, EC 241309, DB 1588, DS 3109, EC 251358, JS 20-79, JS 21-17, VP 1164, JS 20-69, JS 20-34, JS 20-53 and MACS 1620 were found absolute resistant. Likewise eighteen genotypes reacted as moderate resistant and remaining seventeen were exhibited moderate susceptible to susceptible reaction.

Table.1 Ratings/ grades based on the percent leaf area infected

\begin{tabular}{|l|l|}
\hline Rating & Descriptions \\
\hline $\mathbf{0}$ & No lesions/spots \\
\hline $\mathbf{1}$ & $1 \%$ leaf area covered with lesions/spots \\
\hline $\mathbf{3}$ & 1.1 to $10 \%$ leaf area covered with lesions/spots, no spots on stem \\
\hline $\mathbf{5}$ & 10.1 to $25 \%$ of leaf area covered, no defoliation; little damage \\
\hline $\mathbf{7}$ & $\begin{array}{l}25.1 \text { to } 50 \% \text { leaf area covered; some leaves drop; death of a few plants, damage } \\
\text { conspicuous }\end{array}$ \\
\hline $\mathbf{9}$ & $\begin{array}{l}\text { More than } 50 \% \text { area covered, lesions/spots very common on all plants, defoliation } \\
\text { common; death of plants common; damage more than } 50 \% \text {. }\end{array}$ \\
\hline
\end{tabular}


Table.1A Reaction of soybean genotypes against Rhizoctonia Aerial Blight (RAB) and Charcoal rot (CR) during Kharif - 2019

\begin{tabular}{|c|c|c|c|c|c|}
\hline \multirow[t]{2}{*}{ S.N. } & \multirow[t]{2}{*}{ Genotypes } & \multicolumn{2}{|c|}{ RAB } & \multicolumn{2}{|c|}{ CR } \\
\hline & & PDI & Reaction & Score & Reaction \\
\hline 1 & DS 3109 & 4.75 & MR & 0 & $\mathrm{AR}$ \\
\hline 2 & JS 20-51 & 27.45 & S & 3 & MR \\
\hline 3 & EC 109540 & 18.20 & MS & 5 & MS \\
\hline 4 & NRC 67 & 14.83 & MS & 3 & MR \\
\hline 5 & JS 21-71 & 0.75 & HR & 0 & $\mathrm{AR}$ \\
\hline 6 & EC 107407 & 22.43 & MS & 5 & MS \\
\hline 7 & CAT $1241 \mathrm{~A}$ & 4.58 & MR & 3 & MR \\
\hline 8 & EC 251358 & 8.25 & MR & 0 & $\mathrm{AR}$ \\
\hline 9 & JS 20-37 & 14.30 & MS & 5 & MS \\
\hline 10 & EC 241309 & 16.26 & MS & 0 & $\mathrm{AR}$ \\
\hline 11 & DB 1588 & 23.50 & MS & 0 & $\mathrm{AR}$ \\
\hline 12 & PS 1347 & 19.45 & MS & 3 & MR \\
\hline 13 & JS 21-08 & 23.80 & MS & 3 & MR \\
\hline 14 & P501 & 20.15 & MS & 5 & MS \\
\hline 15 & JS 20-79 & 8.56 & MR & 0 & $\mathrm{AR}$ \\
\hline 16 & EC 245986 & 33.50 & $\mathrm{~S}$ & 5 & MS \\
\hline 17 & EC 7048 & 21.35 & MS & 3 & MR \\
\hline 18 & JS 20-82 & 20.30 & MS & 7 & $S$ \\
\hline 19 & EC 250591 & 30.40 & $\mathrm{~S}$ & 5 & MS \\
\hline 20 & JS 20-31 & 0.87 & HR & 0 & $\mathrm{AR}$ \\
\hline 21 & AGS 95 & 18.30 & MS & 5 & MS \\
\hline 22 & M 204 & 16.53 & MS & 7 & $\mathrm{~S}$ \\
\hline 23 & JS 20-67 & 18.0 & MS & 9 & HS \\
\hline 24 & EC 291398 & 21.43 & MS & 7 & S \\
\hline 25 & EC 242104 & 20.50 & MS & 3 & MR \\
\hline 26 & EC 457286 & 14.33 & MS & 9 & HS \\
\hline 27 & EC 39177 & 4.50 & MR & 9 & HS \\
\hline 28 & TG $\mathrm{x}-849 \mathrm{D}-13-4$ & 0.87 & HR & 0 & AR \\
\hline 29 & EC 241778 & 22.3 & MS & 3 & MR \\
\hline 30 & JS 21-17 & 2.57 & MR & 0 & AR \\
\hline 31 & BHATT & 4.60 & MR & 9 & HS \\
\hline 32 & JS 20-42 & 0.75 & HR & 0 & AR \\
\hline 33 & VP 1162 & 4.20 & MR & 5 & MS \\
\hline 34 & VP 1164 & 3.85 & MR & 0 & AR \\
\hline 35 & JS 20-69 & 8.78 & MR & 0 & $\mathrm{AR}$ \\
\hline 36 & EC 241807 & 7.43 & MR & 5 & MS \\
\hline 37 & PI 210178 & 17.30 & MS & 7 & $\mathrm{~S}$ \\
\hline 38 & ANKUR & 19.20 & MS & 9 & HS \\
\hline
\end{tabular}




\begin{tabular}{|l|c|c|c|c|c|}
\hline $\mathbf{3 9}$ & EC 114573 & 8.55 & MR & 9 & HS \\
\hline $\mathbf{4 0}$ & NRC 84 & 18.40 & MS & 3 & MR \\
\hline $\mathbf{4 1}$ & JS $20-65$ & 37.50 & S & 3 & MR \\
\hline $\mathbf{4 2}$ & Dsb 21 & 18.45 & MS & 9 & HS \\
\hline $\mathbf{4 3}$ & EC 291448 & 28.60 & S & 3 & MR \\
\hline $\mathbf{4 4}$ & JS $20-34$ & 7.80 & MR & 0 & AR \\
\hline $\mathbf{4 5}$ & GP 448 & 31.50 & S & 5 & MS \\
\hline $\mathbf{4 6}$ & PLS 057 & 33.25 & S & 5 & MS \\
\hline $\mathbf{4 7}$ & EC 241696 & 21.67 & MS & 3 & MR \\
\hline $\mathbf{4 8}$ & EC 241771 & 18.75 & MS & 3 & MR \\
\hline $\mathbf{4 9}$ & EC 1619 & 20.45 & MS & 3 & MR \\
\hline $\mathbf{5 0}$ & NRC 71 & 23.85 & MS & 3 & MR \\
\hline $\mathbf{5 1}$ & JS 20-53 & 7.90 & MR & 0 & AR \\
\hline $\mathbf{5 2}$ & EC 358002 & 17.53 & MS & 3 & MR \\
\hline $\mathbf{5 3}$ & EC 241777 & 20.40 & MS & 3 & MR \\
\hline $\mathbf{5 4}$ & JS 20-75 & 0.85 & HR & 0 & AR \\
\hline $\mathbf{5 5}$ & MACS 1620 & 5.60 & MR & 0 & AR \\
\hline $\mathbf{5 6}$ & SHIVALIK (c) & 23.4 & MS & 5 & MS \\
\hline $\mathbf{5 7}$ & JS 95-60(c) & 8.57 & MR & 9 & HS \\
\hline $\mathbf{5 8}$ & JS 93-05(c) & 19.80 & MS & 9 & HS \\
\hline $\mathbf{5 9}$ & JS 335(c) & 22.50 & MS & 3 & MR \\
\hline $\mathbf{6 0}$ & NRC 7 (c) & 19.65 & MS & 5 & S \\
\hline
\end{tabular}

Table.2 Soybean genotypes showing dual resistance against Charcoal rot (CR) plus Rhizoctonia Aerial Blight (RAB) during Kharif- 2019

\begin{tabular}{|c|c|c|}
\hline Diseases & Genotypes & Total \\
\hline $\begin{array}{c}\text { Charcoal rot (AR) } \\
+ \text { Aerial blight }(\mathbf{H R})\end{array}$ & JS 21-71, JS 20-31, TG x - 849D-13-4, JS 20-42, JS 20-75 & 5 \\
\hline $\begin{array}{c}\text { Charcoal rot (AR) } \\
+ \text { Aerial blight (MR) }\end{array}$ & DS 3109, EC 251358, JS 20-79, JS 21-17, VP 1164, JS 20- & 9 \\
\hline $\begin{array}{c}\text { Charcoal rot (MR) } \\
+ \text { Aerial blight (MR) }\end{array}$ & 69, JS 20-34, JS 20-53, MACS 1620 & \\
\hline
\end{tabular}


Photo.1 Showing complete mortality (A) and blackening of infected root due to Charcoal rot (B) and close up of progressing of Aerial blight in susceptible genotypes (C), respectively

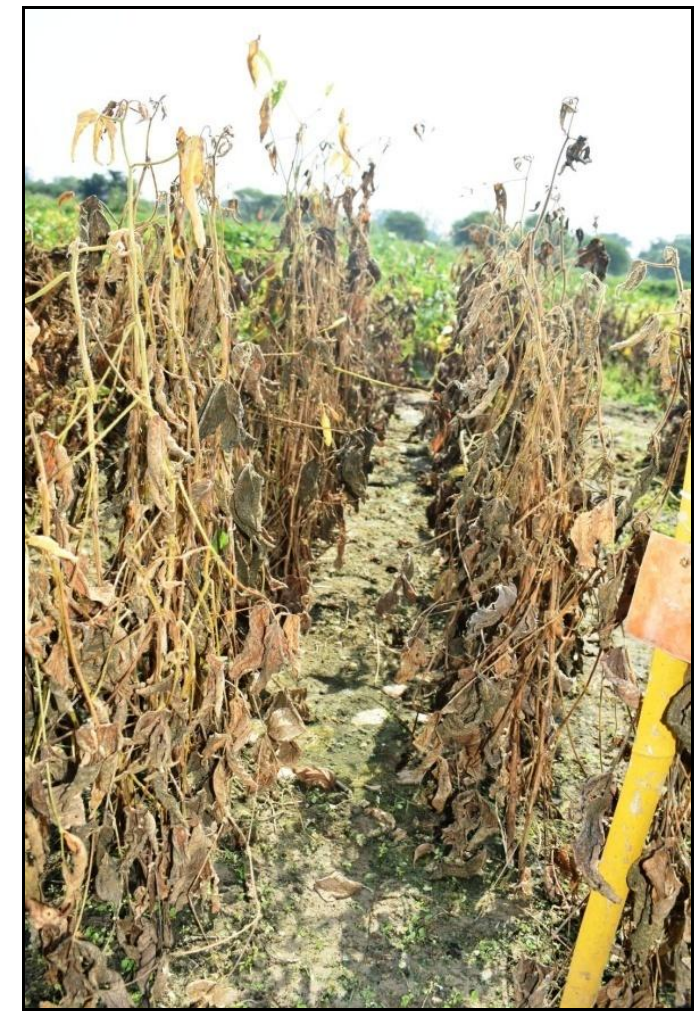

A

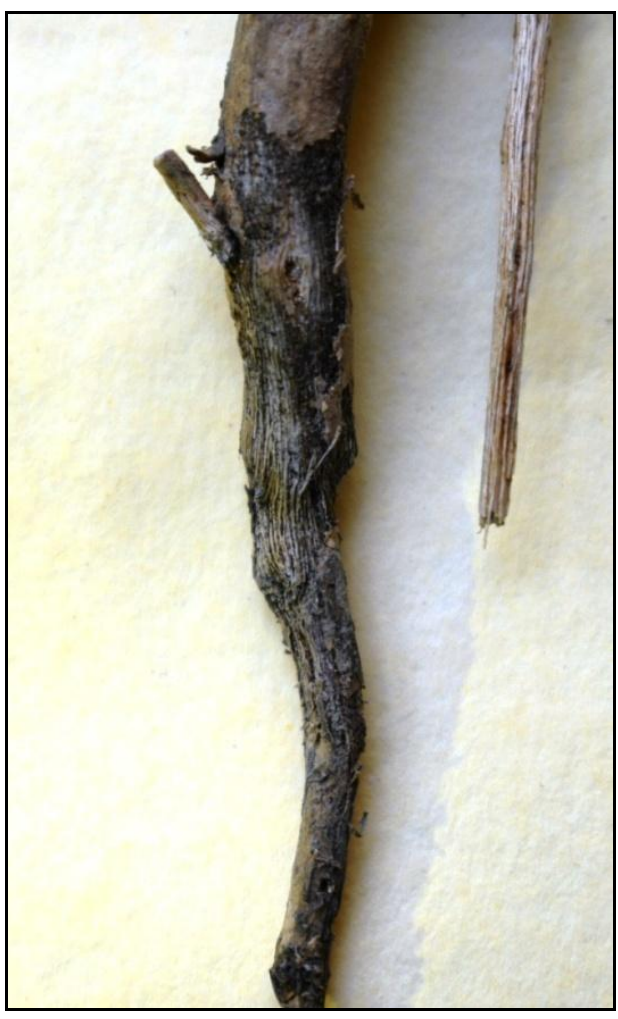

B

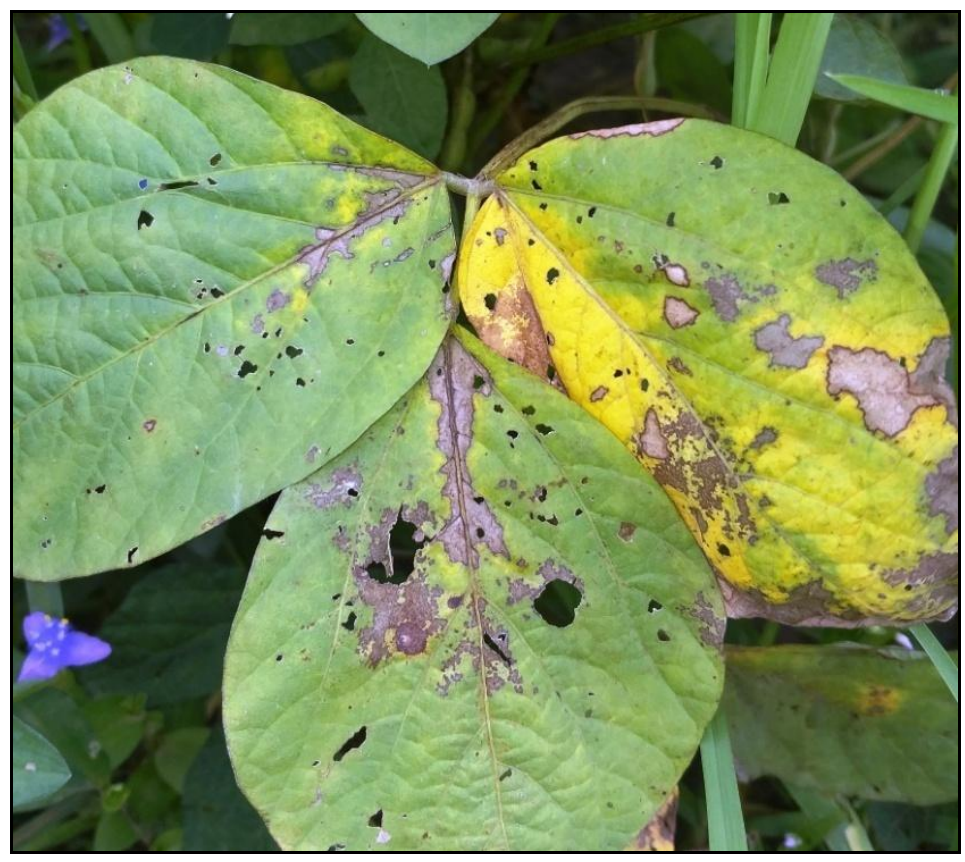

C 


\section{Resistant to both diseases}

Only few genotypes were reported dual resistance against both the diseases. Of this, five namely JS 21-71, JS 20-31, TG x 849D-13-4, JS 20-42 and JS 20-75 shown absolute resistance to $\mathrm{CR}$ plus highly resistance to RAB. Whereas nine i.e. DS 3109, EC 251358, JS 20-79, JS 21-17, VP 1164, JS 20-69, JS 20-34, JS 20-53, MACS 1620 and one namely CAT $1241 \mathrm{~A}$ found to be absolute resistant (CR) plus moderately resistant (RAB) and moderately resistant (CR plus RAB), respectively.

In India, several workers have reported different level of resistance against both the disease. Gopal and Jagadeeshwar (1997) found highest incidence of 86.8 per cent of charcoal rot in soybean during screening of different genotypes and these were also grouped accordingly their resistance level. Singh (2009) and Patel (2011) screened resistance against $R$. solani causing Aerial blight of soybean and findings were categorized in to highly resistant to highly susceptible. Amrate et al., (2018) also evaluated one hundred and nineteen genotypes in Madhya Pradesh agro condition and reported twenty nine genotypes as highly resistant against charcoal rot and Aerial blight.

\section{Acknowledgment}

We are highly thankful to IISR, Indore for providing some of entries which included in this trial for resistance screening purpose.

\section{References}

Amrate, P.K., Pancheshwar, D.K., and Shrivastava M.K., 2018. Evaluation of soybean germplasm against charcoal rot, aerial blight and yellow mosaic virus disease in Madhya Pradesh. Pl. Dis. Res. 33 (2): 185-190.

Anonymous. (2012). In: Proceedings and technical programmes (2012-13) of 42nd Annual group meeting CSK Himachal Pradesh Krishi Vishwavidyalaya, Palampur (Himachal Pradesh) March 2224. 2012, 68pp.

Anonymous. (2018). The Soybean Processors Association of India (SOPA) report http://www.sopa.org/india-oilseeds-areaproduction-and-productivity/.

Bradley, C.A. and Rio, L.E. (2003). First report of charcoal rot on soybean caused by Macrophomina phaseolina in North Dakota. Plant Dis. 87(5): 601.

Gopal, K. and Jagadeeshwar, R. (1997). Reaction of soybean genotypes to charcoal rot (Macrophomina phaseolina). J. Mycol. Pl. Pathol. 27 (1): 87-88.

Patel, K. (2011). Studies on Rhizoctonia aerial blight with special reference to identify the source of resistance in soybean (Glycine max (L) Merrill). M.Sc. Thesis, J.N.K.V.V., Jabalpur.

Singh, R. (2009). Studies on variability among two anastomosis groups of Rhizoctonia solani Kuhn causing aerial blight of soybean [Glycine $\max (\mathrm{L}$.$) Merrill]. M.sc.$ Thesis, J.N.K.V.V., Jabalpur.

Verma, H.S. and Thapliyal, P.N. (1976). Rhizoctonia aerial blight of soybean. Indian Phytopath. 29(4): 389-391.

Wheeler, B.E.J. (1969). An Introduction to Plant Diseases. John Wiley and Sons Ltd., London. 301pp.

\section{How to cite this article:}

Pawan K. Amrate, M. K. Shrivastava and Gyanendra Singh. 2020. Screening of Genotypes to Identify the Resistance Source against Major Diseases of Soybean under High Disease Pressure Conditions. Int.J.Curr.Microbiol.App.Sci. 9(05): 1739-1745. doi: https://doi.org/10.20546/ijcmas.2020.905.195 